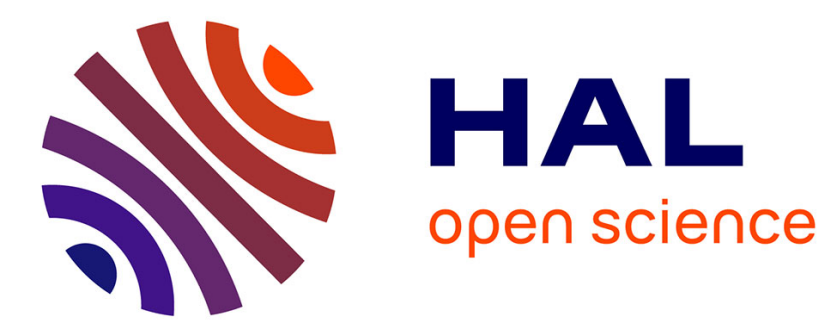

\title{
Empty stocks and loose paper: Governing access to medicines through informality in Northern India
}

\author{
Marine Al Dahdah, Aalok Kumar, Mathieu Quet
}

\section{To cite this version:}

Marine Al Dahdah, Aalok Kumar, Mathieu Quet. Empty stocks and loose paper: Governing access to medicines through informality in Northern India. International Sociology, 2018, 33 (6), pp.778-795. 10.1177/0268580918792779. hal-02520023

\section{HAL Id: hal-02520023 https://hal.science/hal-02520023}

Submitted on 2 Apr 2020

HAL is a multi-disciplinary open access archive for the deposit and dissemination of scientific research documents, whether they are published or not. The documents may come from teaching and research institutions in France or abroad, or from public or private research centers.
L'archive ouverte pluridisciplinaire HAL, est destinée au dépôt et à la diffusion de documents scientifiques de niveau recherche, publiés ou non, émanant des établissements d'enseignement et de recherche français ou étrangers, des laboratoires publics ou privés. 
Empty stocks and loose paper: Governing access to medicines through informality in Northern India
International Sociology

$1-18$

(C) The Author(s) 2018

Article reuse guidelines: sagepub.com/journals-permissions DOI: $10.1177 / 0268580918792779$ journals.sagepub.com/home/iss

\title{
Marine Al Dahdah
}

IFRIS- Paris Descartes University (Cermes3), France; CSH-Delhi, India

\section{Aalok Kumar}

Independent researcher, Patna, India

\section{Mathieu Quet}

CEPED, Paris Descartes University-IRD, France; Jawaharlal Nehru University, India

\begin{abstract}
Based upon research in the state of Bihar, India, this article argues that informal access to medicines in Northern India is a core element of the government of healthcare. Informal providers such as unlicensed village doctors and unlicensed drug sellers play a major role in access to medicines in Bihar, in the particular context of the dismantling of public procurement services. Building on recent works in the socio-anthropology of pharmaceuticals, the article shows the importance of taking into account the political economy of drugs in India, in order to understand local problems of access more fully. If informal providers occupy such an important position in the government of healthcare in India, this is partly due to the shaping of healthcare as access to drugs on health markets. Elaborating the argument from interviews with health professionals and patients, the article first shows the situation of public healthcare and public procurement in Bihar; then it presents the role of informal medicine providers; lastly, it shows how patients deal with the fact that they live in a 'pharmaceutical world' where access to health equates with access to medicines.
\end{abstract}

\section{Keywords}

Access to medicines, Bihar, India, informal markets, public procurement, sociology of health

\section{Corresponding author:}

Marine Al Dahdah, Paris Descartes University, Cermes3, 45 rue des Saints Pères, Île-de-France 75006 Paris, France.

Email: marine.aldahdah@gmail.com 


\section{Introduction}

The debate on informal healthcare providers (IPs) in the Global South comprises two main opposing views on the role played by this category as regards access to healthcare services (Das, 2016). The first group, whose arguments are vocally supported by the Indian Medical Association, has been traditionally opposed to the professional recognition of informal providers, arguing that only officially trained and licensed practitioners are entitled to provide care. Advocates of this approach underline the risks that would be presented by recognition of IPs: it would legitimize an illegal practice and could have disastrous effects upon patients. Against this 'legalist' approach, some public health works on IPs emphasize the need for a better integration of IPs in the healthcare delivery system (for instance through training) (Das and Barnwal, 2018; Das et al., 2016), following a trend already existing since the Alma Ata Declaration in 1978. They acknowledge the important role played by IPs in terms of access to healthcare and treatment, especially in rural and poor areas, and underline the bridges that exist - and should be enhanced according to them - between the informal and formal sectors. This view claims the necessity to build a healthcare system on the basis of existing institutions and practices - and qualifies therefore as 'realist'.

We propose to take a different stance, based upon our fieldwork research in rural Bihar (India). We contend that as different as they are, both 'legalist' and 'realist' discourses share a common view on the informal practice as materializing the existence of a parallel health market, 'on the margins of formalized medicine' (Gautham et al., 2014), out of the reach of regulatory authorities and most importantly, outside the realm of government and the state. Contrary to that shared view, we will show that not only are IPs essential components of the health system from the patient perspective - a point that has well been demonstrated by others (Gautham et al., 2014; May et al., 2014) - but also that they are integral to the way the Indian state today assumes its functions in rural and deprived areas. In that sense, the term 'informal' can be misleading, as anthropologist Janet Roitman has shown in the case of informal economy: whereas informal economy is 'often signaled as a residual category', it can be 'at the heart of productive economic life' (Roitman, 2005: 20). Informal health markets indeed appear to be at the heart of medical life in rural Bihar, simultaneously from the point of view of patients, public and private practitioners, and authorities. Informality then constitutes one crucial aspect of the government of healthcare in the rural areas of India and plays a crucial part in the contemporary 'government rationale' (in the sense of Foucault, 2004). According to Foucault, the analysis of power should not be reduced to the state's main attributes (such as the parliament or the army). Rather, power spreads within the multiple sites and moments that compose social life. In that sense, one can identify the exercise of power not only in governmental declarations and state actions, but also in what is typically not taken charge of by the state, and appears to be left to the people, be it attributed to a lack of will, justified by the production of a particular knowledge, or even due to simple ignorance.

The nature of such a government has however to be clarified in order to make the argument more specific. As will be shown, our argument is first of all mostly valid if we understand the healthcare system as one of access to medicines (and not, more broadly, to care) in the context of the Indian liberalized market that constitutes a particular ecology of 
access to health. This implies an analytical approach that takes into consideration not only retail and consumption practices, but also the broader economic and political organization of production and procurement, following recent works in the socio-anthropology of pharmaceuticals (Baxerres, 2011; Desclaux and Egrot, 2015; Ecks and Harper, 2013; Peterson, 2014; Sunder Rajan, 2017). Healthcare being equated with access to medicines, the Indian nation can be thought of by its leaders as a large market for pharmaceuticals, and governed accordingly.

In a way, this work pursues earlier research by anthropologist Sarah Pinto, who has described how informal (ersatz) medicine is entangled with conceptions of institutional health, power and government (Pinto, 2004). Furthermore, our argument follows what sociologist Jan Breman has shown in the case of the informal economy in India, where he explains that informal economy should be seen as part of the wider logic of unregulated capitalism (Breman, 2014). It is therefore inscribed in a critique which has, for decades now, opposed the idea that an economy is dual - insisting on the linkages between formal and informal rather than on their separateness (Breman, 1976; Bromley and Gerry, 1979). It is also inscribed in analyses of capitalism focusing upon the informal not only as a sector but also as a process related to the global transformations of capitalism - described as informalization (Sassen, 1994).

So to make our point, we rely upon a study combining sociological interviews and qualitative ethnographic observation. The interviews and observations were led by the three authors in Bihar in December 2016, with one of the authors (AK) having led preliminary research and sample selection during the earlier part of 2016. Our investigation was carried out in one particular district of Bihar and in several blocks, that is to say sub-districts. The choice of this district was doubly motivated. First, it was listed by the government of India as a high priority district (among the bottom 25\% of districts in each state, based on a composite health index), which suggested that issues related to access to medicines would be greater than in other districts. ${ }^{1}$ Second, among the high priority districts situated in Bihar, this one has been extensively studied by one of the authors as part of a wider project on Bihar rural livelihoods. Purposive sampling was used to carry out in-depth sociological interviews with public and private health providers and patients. We conducted qualitative face-to-face interviews with 31 public health providers (at primary health centre, block and district level), 30 private providers (informal and formal) and 40 patients. We met drug administrators, managers, health workers, drug sellers, village doctors and patients in different villages, village clinics, drug stores, primary health centres, referral or district hospitals - all involved in the prescription, provision or consumption of medicines in this same district. ${ }^{2}$ The interviews were conducted in Hindi, fully transcribed into English and encoded through a two-step coding method (descriptive and analytical) in NVivo software (Saldaña, 2009) before conducting the analysis.

In the first section, we explain how the space for informality is inherently built into the public healthcare system. It implies acquiring a broader view of the pharmaceutical supply chain and explaining how dysfunctions are identified and managed within this system. In the second section, we present the so-called informal sector, focusing upon its role in access to medicines and reflecting upon the consequences for people who live in a world that conflates caregiving with drug provision. 


\section{Part I: Failure of public provision of medicines or the turn toward an unregulated drug market?}

The main provider of health and medicines in Bihar is supposedly the public healthcare system, meaning if people are sick they can turn to public infrastructures to be taken care of. First, we will present a concise overview of the public health system to understand where and from whom people are requesting drugs in the public system and we will also briefly introduce the public system of drug procurement to see where the drugs come from and how they circulate in the public system. Then we will describe the multiple difficulties and shortcomings of this public provider that explain the patient's turn toward private and informal providers of medicines.

\section{The maze of public provision of medicines}

In India urban and rural health is built on different architectures. As is nationally prescribed for rural areas, public health facilities in rural Bihar are organized on a multilevel system and are linked by a referral system - that patients rarely follow, as explained further. The subcentre, the lowest level of the public health infrastructure, covers several villages (on average 5000-6000 people) and serves as the entry point between the community and the formal public healthcare system. The next level of facilities consists of primary health centres (PHCs), which are the first point of contact between individuals and a qualified medical doctor (covering a population between 30,000 and 100,000). There are also a limited number of larger PHCs at the block level (called referral hospitals), which provide similar services but serve a larger population. Each PHC is typically staffed by a doctor, a nurse or an auxiliary nurse midwife (ANM), and a lady health visitor (LHV), who supervises ANMs in the subcentres linked to the PHC. PHCs may refer cases to higher level facilities, like community health centres, subdivisional hospitals and district-level hospitals, which provide some degree of specialist care. Each PHC, subdivisional and district hospital is supposed to have a pharmacist and a drug administrator to manage the emergency, inpatient and outpatient drug stocks of the facility. And patients are supposed to get medicines and treatment for free at all those government facilities. But although the central government launched in 2005 the National Rural Health Mission (NRHM) to improve access to effective healthcare for the poor residing in rural areas and although Bihar was among the priority states of the NRHM, the programme did not bring as much improvement in health expenditure, health infrastructure, human resources for health, or availability of drugs as was expected and mandated by the programme (Rao and Choudhury, 2012).

In India, procurement of medicines in the health system takes place at various levels, namely the national/federal level, state level, local government level and autonomous bodies. In addition, medicines for national disease-control programmes, such as the Revised National Tuberculosis Control Programme, National AIDS Control Programme and others, are procured through a national procurement agency. Indian states procure medicines for their health systems through their own procurement agencies, although they may also receive funding from national government. In this article, we will study only the state level and lower level procurement processes, and we will first present the organizational framework before looking at how it actually functions. 
In theory, the Government of Bihar is committed to provide quality essential generic medicines, free of cost, to all patients coming to government hospitals. In 2012/2013, the government set up the Bihar Medical Services and Infrastructure Corporation Limited (BMSICL) to procure and purchase medications at the state level. Thus, BMSICL is the institution in charge of public procurement of medicines in Bihar. The tender process is supposed to be done every year and needs two months to be completed. Only manufacturers of generic medications are invited. There are two stages to the process: suppliers must satisfy the technical tender before their financial bid is considered. Generally a minimum of four to five bids is received for each medication. The volumes of medicines required are pooled at the state level and rate contracted, while actual invoicing and payment are normally done at district level. To ensure that a minimum number of drugs for all therapeutic specialties remain available in all health facilities at all times, a list of essential drugs has been prepared to satisfy the priority healthcare needs of the population. Those essential drugs are distributed from the selected manufacturers to regional warehouses where medications are stored, and then delivered to the district drug stores; from there public facilities have to come and pick their orders themselves.

In addition to the BMSICL cash and carry system, there are multiple mechanisms for drug procurement at the district level, which include buying drugs without quotations, three quotations and open tender within thresholds defined by the Bihar Finance Rules 2005, or through orders passed by the District Collector, which we will not discuss in this article. That way, if the public facilities need other drugs or if they have urgent needs that the BMSICL procurement process cannot fulfil, each facility can use one of the local procurement systems. For instance, a PHC can order drugs for a maximum 15,000 rupees each time up to 100,000 rupees per year from wholesalers selected by the district (there were two selected wholesalers in our studied district for example). As we will see in the next section though, this procurement system exists mostly on paper and is highly inefficient.

\section{Understaffed, undersupplied and underfunded public infrastructures}

The Indian healthcare system is regularly criticized for the low level of central and regional government involvement in public health spending, the chronic dysfunctional health infrastructures and health supply chains and the massive inequalities in health, reinforced by caste, class, religion, or gender. Jean Drèze and Amartya Sen refer to the Indian health system as 'mercantile': a 'market system where diagnoses and drugs are treated much like any other commodity' (Drèze and Sen, 2002: 202). Numerous studies show that the quality and accessibility of health services and medicines have deteriorated overall in the country (Das, 2015; Drèze and Sen, 2013; Hodges and Rao, 2016; Pinto, 2008). Although district hospitals, primary health centres, or subcentres exist, resources are squandered, facilities are understaffed and undersupplied. Rao et al. (2011) report that in 2005 only 3.8 doctors were operating per 10,000 people in India (the WHO recommends a minimum ratio of 10/10,000). This situation is not new, as shown for instance in long-term investigations into maternal health in Uttar Pradesh by Jeffery and colleagues (Jeffery and Jeffery, 2008; Jeffery et al., 1984, 1987). This has in turn affected the confidence of people in the quality of public health services (Jeffery and Jeffery, 2010). 
These general observations are exacerbated in Bihar. The BIMARU ${ }^{3}$ states comprising Bihar, Madhya Pradesh (MP), Rajasthan and Uttar Pradesh (UP) have long been identified as lagging behind in respect of most indices of economic growth and human and infrastructural development. And Bihar among them is repeatedly pinpointed as the worst performing state. Bihar is one of India's poorest states, and its health and development indicators point to high levels of poverty and poor health. The state faces continuing public health challenges, with high rates of child and maternal mortality, fertility and undernutrition. Accounting for about $8 \%$ of India's population and $10 \%$ of its annual births, Bihar contributes to $12 \%$ of national maternal deaths, $12 \%$ of neonatal deaths and $15 \%$ of underweight children. ${ }^{4}$

The Government of Bihar has made major strides in the past several years, introducing new policies aimed at improving transportation and physical infrastructures, with a focus on health and education sectors. This has resulted in high levels of economic growth, with state gross domestic product almost doubling from 2005 to 2010, albeit from a very low base (Central Statistics Office, 2012). Several health indicators also improved substantially over this period: for example, the percentage of women giving birth at a facility increased from 22 to 67\% between 2005-2006 and 2015-2016 (Indian National Family Health Survey, 2005-2006, 2015-2016). Despite these changes, important gaps persist in the health practices of households and in service provision, and the health outcomes of Bihar's population still need considerable improvement. Our investigation shows multiple difficulties for individuals in accessing health services and medicines. In Bihar, health facilities are dysfunctional and public money or goods do not always reach the district, the block level and even less out to the villagers.

First, the health system lacks human resources. Bihar with $8 \%$ of the national population has only $4.42 \%$ of the country's health workers and our district of study is among the 30 worst districts in India in terms of health worker density. ${ }^{5}$ As in the rest of India, public health administration is chronically understaffed in Bihar. One-third of the block manager positions are vacant across the country and almost half in Bihar, as shown by the example of a referral 100-bed hospital where the manager and the medical officer in charge were in fact splitting their time between two hospitals in two different blocks: 'The Medical officer in charge is in charge of another block too. I am also the block health manager of another block. I stay three days here and three days there. So it is not easy for me to run the facility like this.' ${ }^{6}$ In the surveyed district, many block health manager or medical officer positions were not filled and therefore had to be assumed by the manager or doctor of another facility, entailing an serious overload of work for them.

Second, there is a lack of money to run the facilities which coincides with the lack of staff. The referral hospital which is supposed to run with more than 100 staff members and a budget for 100 beds is in reality running with six health workers ( 4 nurses, 1 doctor and 1 counsellor) and on a PHC fund for 10 beds: 'I have been given an elephant to maintain with the funding of a PHC. By the time the human resources finally come here, the infrastructure will be damaged and long gone already. ${ }^{7}$ The PHCs are severely understaffed and moreover they are currently serving 7 to 10 times the population they should actually serve, meaning that even if they were getting the sanctioned staff levels and budget, those would not be enough to contain the numbers of patients that are arriving at the PHC level.

Third, there is a lack of presence, which has already been pointed out by other studies: Banerjee et al. (2004) noted an absenteeism rate of $36 \%$ at the PHC level and $45 \%$ at the 
subcentre level in a study in Udaipur, Rajasthan. Appointed staff are not coming to the facility. Doctors are often accused of spending more time running their private clinic than coming to the PHC where they are supposed to be. Pharmacists in charge at the block level were never on site when we conducted our investigation: most of the time ANMs or drug administrators with no specific pharmaceutical training were in charge of medicine stocks and distribution: 'Most of them [PHC pharmacists] are absent most of the times. They do not have any accountability.' 8 The only PHC pharmacist we interviewed has been working for eight years as the pharmacist in charge with no pharmaceutical degree because there was no one else to take care of the drugs. Because of lack of staff, funding and accountability, hospitals are struggling to function under terrible conditions in Bihar.

\section{Scams, stock outs and scarcity: The insufficient flows of medicines}

In 2014, BMSICL, the public agency in charge of providing medicines, was involved in a massive scam around the purchase of medicines. It purchased drugs worth Rs.14.48 crore (almost US\$3 million) at a rate of 10 to $300 \%$ higher than what was fixed by the state and drugs worth Rs. 19.60 crore (almost US\$4 million) from two companies which were blacklisted. Since then the public procurement of medicines through BMSICL is considered by most of the actors to be dysfunctional and poor. BMSICL is supposed to provide 33 outpatient medicines and 112 emergency and inpatient medicines to each and every district hospital in Bihar: 'The government says that more than 100 types of essential drugs must be available whereas you can come to the district drug store and see for yourself that only 10-15 types of drugs are available.' ${ }^{9}$ Medicines are not coming in at the district level in sufficient amounts and this has important repercussions at the facility level. In the facilities we surveyed, essential drugs were not all available, nor in the required quantities: 'We do not get medicines as per our demand because they provide us medicines according to their stock. For 18 months now, the condition is really poor. This problem is with all the medicines.' ${ }^{10}$ At the block level, when we asked which medicines had been used over the past six months for outreach, the ANMs replied: 'Medicines for outreach are out of supply';11 when we asked about medicines for diarrhoea they told us: 'There is [a] shortage running for a long time.' ${ }^{2}$ 'All the medicines are available in limited quantities.' 13

Thus most of the patients get fewer medicines than what is prescribed to them: 'it's [a] first come first served basis'. ${ }^{14}$ Patients are not getting the medicines they need at the government facilities, and if they want their full treatment they will have to come back another time hoping that they will get what they need after several attempts or most probably they will purchase those medicines outside the PHC, in fact just in front of it, from the plethora of unregulated private providers that flourish there.

\section{Part 2: Informal healthcare-providing services as part of the government of healthcare in rural India}

\section{Governing through informality}

As a counterpart to the underfunded, understaffed public sector, constantly low on stock, the private healthcare sector is flourishing in India. In this article we focus upon the 
informal access to medicines provided through this sector, as part of the government of a healthcare rationale. A first reason that leads us to interpret informality in that way ( $a$ la Foucault) is the inclusion of informal healthcare providers as part of the government strategy to administer healthcare, both at a state and central level. As mentioned by Rao et al. (2011), some small-scale initiatives have been taken, following the example of the Chinese barefoot doctors in the 1970s, and later in line with the Alma Ata Declaration. More recently, at the central level, the 11th and 12th Five-Year Plans have called for a better integration of the informal providers into the health system (Gautham et al., 2014). At the state level, a one-year training scheme for 'untrained health workers' was launched in August 2015 at the National Institute of Open Schooling in order to integrate unlicensed medical practitioners into the healthcare system through learning rather than to take action against these important players in the field. The course has been designed but is however still pending approval from the government. It is worth noting, however, that such initiatives in India have not been very successful, given the lack of support and the difficulties to define clearly the roles of the different stakeholders (Rao et al., 2011).

But for Foucault, governing is not solely the privilege of governments and one should analyse a governmental rationale from observations not limited to institutional initiatives. The argument should therefore take a less institutional view of healthcare: 'telle qu'elle se fait' ('as it is being done') to quote Michel Callon and Bruno Latour (1990). Indeed, if one looks at the actual access to medicines in Bihar, it is obvious that informal providers are only one symptom of the under-regulation of 'drug circuits' (Peterson, 2014). They are part of a wide range of actors involved in the distribution of medicines, occupying varied positions and transgressing rules and standards at different levels. First are the gaon ka doctors, often called quacks by formal healthcare providers as well as some patients. They provide care and sell medicines in the villages. Most of our interviewees had no licence, no diploma, no training entitling them to prescribe or to sell medicines. They were delivering different kinds of medicines, from vitamins to antibiotics. The situation of the gaon ka doctors, as care and medicine providers, gives them a particular position within the pharmaceutical regulatory system that they use to overcome stringent rulings:

Question: Do you need a licence even in villages to run a medical shop?

Answer: Of course, if you run a medical store even in a village, you need licence for it.

Q: $\quad$ Do you have a licence?

A: No, this is not even a shop. We are rural medical practitioners [RMPs]. This is being done as a social work.

Q: $\quad$ Is there some certificate for RMPs?

A: $\quad$ Yes, for RMPs a rural medicine certificate is given. It is given from Patna. You have to complete a six months course for that. We haven't done any such course. ${ }^{15}$

Most of them got their medicines from private retailers locally, though some were in contact with wholesale agencies in the district capital. It is also notable that among the gaon ka doctors we interviewed, several of them had direct contacts with drug 
retailers. In some instances, one member of the family operated as a doctor while the other ran a drug shop.

The gaon ka doctors are far from being the only health providers acting outside of the regulatory framework. Second to them are drug retailers who do not have any diploma or licence to sell medicines: in other words, no legal authorization to retail drugs. Third are retailers who have no diploma, therefore are not registered pharmacists, but have a licence. This practice is common and many of the retailers we interviewed declared they had managed to get a licence thanks to friends or family members themselves registered. In that case the interpretation of the Drugs and Cosmetics Act is very loose since prescription medicines should be sold 'under the direct supervision of a registered pharmacist', and one can wonder how direct this supervision is when the licensee is living a few hundred kilometres away from the retail shop, and when it is admitted that he/she never comes to the shop. As this drug inspector explains: 'In Bihar, there are around 15,000 registered pharmacists whereas there are roughly 65,000 retailers. It means that false certificates have been issued.' ${ }^{16}$ Fourth was the category of registered, licensed pharmacists. Only one of the drug retailers we interviewed was in that situation. But for all of these categories, the sale of prescription medicines needs to be done 'on prescription of registered medical practitioners' and 'shall be effected only by or under the personal supervision of a [registered pharmacist]' (Drugs and Cosmetics Act, 65(2)). One fifth category could also be added: Ayush doctors, supposed to prescribe only medicines from their system of medicines, but who often engage in mixed practice and prescribe allopathic medicines (Rao et al., 2013). The only Ayush doctor met in a PHC during our investigation explained that he had to prescribe allopathic medicines since ayurvedic medicines were never available at the centre. These multiple categories show that 'informal' is a broad category that describes very different situations through which the act of providing medicines is often realized outside of the legal framework.

What matters to our argument here is first that 'informal provision' as regards medicines is a broad category that concerns both licensed and unlicensed, trained and untrained actors. But to acknowledge that these practices form part and parcel of a 'governmental rationale', one has to show how these practices, rather than being deviations from the norm, are fully known by the other actors in the field who get involved in them. In that way we follow Roitman (2005) in her analysis of a plural regulatory authority, through which marginal activity is sometimes regularized by official state representatives or economic actors through non-official means. This point makes more sense if one notes that regulatory authorities can be part of the situation, for two reasons. One is the lack of them: as shown by Kadam et al. (2016) and denounced in many reports to the Indian government since the 1970 s, there are not enough drug inspectors to ensure a proper control; the lack of human resources which affects regulatory authorities, as the rest of the health system, makes it easier to operate outside of the formal market. The second reason is that the drug inspectors used to accept chai-pani (bribes) in order to facilitate or make possible licensing processes that would otherwise be impossible. As one gaon ka doctor and medicines retailer explained: 'I was asked to make a new licence some time back. The fee ... was 3300 INR but obviously I can't tell you how much I paid or he will be caught (laughs). ${ }^{\prime}{ }^{17}$ Given the extent of this practice, it would be inappropriate to point only at the corruption of individuals: the state itself participates in the 
legitimization of the human resources involved in the informal provision of medicines, thus promoting the informality of the system by facilitating access to informal working statuses. This can be seen as another way of institutionalizing informality (Quet et al., 2018), besides more socially legitimate practices of training which institutions such as the Red Cross or WHO dispense.

Furthermore, the situation not only involves the informal providers and the regulatory authorities, since more broadly public medical practitioners 'refer' the patients toward the private system while knowing it is largely unregulated. As one MOIC (medical officer in charge) told us: 'We have been ordered not to prescribe medicine from outside. As much as possible, we have to give the drugs from our store. [If we don't have them] we ask the patient if he wants to buy medicines from outside and we write the name of the medicine on a loose paper.' 18 Such referral processes from the public to the private sector are frequent and do not happen only when stocks have run out, but are more largely due to the scarcity incurred by the public sector. One patient explained: 'Though dengue tests were available in the district hospital, when I requested them to conduct the test, they said that they can't waste the testing kit. So I got it done from private.' ${ }^{19}$ Looking at the actual practice of medicine selling and provision, it seems therefore that: (a) a large variety of informal practices exist, and (b) these practices are known, accepted, and even to some extent endorsed by the agents of the state such as regulatory authorities or doctors from the public sector. In that sense, one could argue that informality is part of the government of healthcare in rural Bihar.

\section{A world of pharmaceuticals}

In order to complete the argument, we need to look specifically at the underlying definition of health implied by the government rationale analysed here, which leads us to pay attention to the political economy of pharmaceuticals in which India has been involved for the last decades. First of all is the fact that all the actors informally providing medicines in the area we studied were involved in allopathic medicines. None of the interviewees providing medicines were dealing with traditional, herbal medicines as a major activity, a situation observed in a nuanced fashion by Pinto (2004). Most of the retailers declared not to sell ayurvedic medicines and only a portion of them were retailing industrial traditional products.

Furthermore, even though the gaon ka doctors perform medical operations, most of their work consists in prescribing and selling medicines, which blurs the line between their activity (unlicensed medical practice) and that of most of the drug retailers we met (unauthorized prescription drug selling). Though not all the gaon ka doctors said so, some of them told us that their only remuneration was from the selling of the medicines they prescribed. They were taking a $10-15 \%$ cut out of the medicines they were selling to the patients. On that basis, the difference between gaon ka doctors and other drug retailers who can also perform simple operations such as injections is blurred and justifies the inclusion in the category of 'informal healthcare provider' both gaon ka doctors and the unregistered pharmacists selling drugs and registered pharmacists selling prescription drugs without prescription.

This implies in turn that the notion of healthcare at issue here is one of equivalence between caregiving and allopathic drug provision. More than that, the access to medicines here takes place in a market that is largely defined by an economic understanding 
of supply and demand, rather than taking into account the socialized nature of goods such as medicines. One illustration of this is the discourse reiterated by retailers or gaon ka doctors linking price and quality: 'Cheaper is expensive. Customer looks for cheaper medicines if you give them cheaper medicine, it wouldn't work. Suppose if you have to eat 10 tablets of a relatively expensive medicine you will have to consume 20 tablets of cheaper medicine to cure the same illness. So, for the patient, it becomes more expensive. ${ }^{20}$ Yet many drug retailers are making profits out of the most expensive drugs since the difference between the maximum retail price (MRP) written on the box and the price paid by them at the stockist is considerable, as this drug inspector explains: 'a cough syrup like Torex. The MRP of this cough syrup is 42 rupees. When you see the bill on which stockist has sold it to the retailer, it's billed at Rs $17.40 .{ }^{21}$ At the same time, retailers and gaon ka doctors adjust their provision according to the economic situation of the patient: 'I give medicines according to the money they have. If they do not have enough money I prescribe them only two tablets and when they have money they buy again.'22 This is a pertinent indicator of the insertion of the providers in a market regulated by laws of supply and demand rather than by particular obligations of care, as has already been put forward by George and Iyer (2013). Furthermore, part of the medical knowledge of the providers comes directly from market actors themselves such as medical representatives and sales persons, as analysed earlier by Kamat and Nichter (1998). This is less the case for gaon $\mathrm{ka}$ doctors, who rarely declared during their interviews that they were receiving visits from sales persons.

These observations show that an equivalence is being made between access to health and access to drug treatments: a phenomenon that has been described as the 'pharmaceuticalization' of society (Biehl, 2007; Desclaux and Egrot, 2015). However this pharmaceuticalization takes a particular shape in the rural landscape of contemporary India. In order to explain it, we now turn to examine the context of the Indian pharmaceutical political economy.

\section{Overflow and scarcity in the neoliberal market}

The impetus of informal private pharmaceutical markets in rural India should not be separated from the larger context of Indian pharmaceutical politics. India is today a pharmaceutical power, often presented as the pharmacy of the (developing) world thanks to a powerful local industry but also described as a huge market in which prices are not controlled, and where the management of health has given way to various forms of 'commercialization' (Hodges and Rao, 2016). Under that particular light, access to medicines is to be understood as a complex encounter between health, industrial and marketing issues (Ecks, 2010; Sunder Rajan, 2017). It appears that informality in health, even though it has been framed by many as a scourge of the nation, is one tool among others to govern with a market understanding of health. Other such problems have been pointed out but they tend mainly to show that access to medicines is profoundly shaped by the influence of industrial firms, and the government's concerns have been more related to facilitating production and marketing than to improving the conditions of access to medicines, as is for instance suggested by Reji K Joseph (2016) in his analysis of the weakness of price control. In other words, it has appeared that during the last 25 
years the Indian government has increasingly thought that what is good for Indian pharmaceutical firms is good for people's health, reminding us of an earlier motto of the state/capitalism alliance.

To emphasize this aspect one can mention some of the public issues related to access to medicines in contemporary India and show how they are related to an industrial and market-biased understanding of such access. Among the multiple 'illnesses' of the Indian pharmaceutical markets, the first is the case of drug price control. The path followed by India regarding this issue has been quite hesitant. Drugs price control was introduced in the 1960s and 1970s in India, in particular through the Drugs (Price Control) Order in 1970. This Order instituted control over pharmaceutical profits, stipulating that pharmaceutical profits should not exceed a limit of $15 \%$. A revised version of the Order in 1979 fixed ceiling prices for a list of 370 medicines. But through the 1980 s to 2000 s the list of medicines has been significantly reduced, in parallel to the rising profits of the national industry. It was only in 2012 that a new Drug Price Order revised the list and brought back around 350 drugs under price control, a number that has increased in the following years. But tensions are still felt around the issue of price control since pharmaceutical lobbying tends to delink the powers of the pharmaceutical pricing authorities from the list of essential medicines. Moreover, drug controllers declare that the influence of local medical representatives and the profits they offer to local doctors is impossible to curb: 'medical representatives who keep visiting the doctors. If the doctors prescribe medicines from these companies, they get 40-50 per cent of the sale value. If they prescribe medicines worth 1 lakh, they would get 40-50k.'23

A second related issue is that of irrational combinations, which are periodically denounced. Combination products or fixed dose drug combinations (FDCs) are pharmaceutical products combining two or more active molecules in a single dosage form. Although these formulations can be very convenient for patients (for instance in HIV and TB therapies) they can also present severe risks of adverse drug effects and drug interactions. The Indian market offers multiple such irrational fixed dose drug combinations, as they have been termed (Gautam and Saha, 2008). Although the situation has been criticized by many authors and organizations, and leads periodically to measures from the government such as the banning of 344 FDCs in March 2016, as explained by this drug inspector these FDCs still find their way to the Indian markets: 'The pharmaceutical companies are very powerful and rich. These are capitalists. They challenged the ban in Delhi High Court. The High Court put a stay on the ban. Recently, the court dismissed the ban.' ${ }^{24}$ It has been argued by some that the situation is due to the ease of registration of medicines in India and the determination of manufacturing companies to overcome price control policies (Thakur, 2016). Authors have noted irregularities in the licences given to the manufacturers of such medicines (McGettigan et al., 2015) and yet these can still be found on the market. Their findings suggest that the regulatory practice encourages manufacturers to put new products such as FDCs on the market without any regard for the consequences for people's health.

Finally, there is the role of the Indian regional states in the regulation of their manufacturing units. Products of questionable quality can enter the market due to high competition and problems keeping pace with the regulatory requirements that have been put in place during the last years and are difficult to apply (see also Kadam et al., 2016). Some 
of our interviewees in the drug retail stores mention the fact that drugs have come on the market in the past which were of bad quality: 'Once, Diclovin (Diclofenac + Paracetamol) had come. It was from a local manufacturer perhaps, probably Kanpur. Whoever ate it showed allergic reactions. Medical stores must have complained against it. It was discontinued.' ${ }^{25}$ Such remarks underline the fact that regulation is often a work done in retrospect, whereas the governments of the states encourage their firms to produce medicine and to sell them in less stringent states such as Bihar.

These different cases show that access to medicines in India is shaped by industrial priorities - producing and marketing medicines - rather than by public health concerns. These concerns result in an overflow rather than a scarcity of medicines on the markets. It is clear that informality, rather than being an evil to be combated by successive Indian governments, is just another tool to facilitate and speed up the flow of goods produced by the Indian pharmaceutical firms.

\section{Conclusion: Pharmaceutical lives}

We have shown how informal drug provision forms a crucial part of the governance of healthcare in Bihar. The assumed failure of the public procurement system and public healthcare system, the multiplicity of private shops and the economic importance of the national drug industry converge to produce a system equating access to healthcare with access to medicines as market. 'What is good for the Indian pharmaceutical industry is good for Indian patients' seems to be the underlying motto ruling access to healthcare in India. But is it that good for patients? Nothing is less sure. At least, this grandfather who went to the PHC with his four-year-old grandson might disagree: 'My grandson was bleeding profusely. It happened in the evening at $7 \mathrm{pm}$. There was no doctor or nurse there [at the PHC]. When I made some noise, the doctor came out and called [a] nurse. He stitched the wound and did the dressing. There was no medicine available. I bought medicines from outside. I had to buy even injection from outside.' ${ }^{26}$ The lack of staff and medicines are the primary cause of mistrust and disappointment with public health infrastructures in the interviews collected.

To conclude this article, we would like to emphasize the difficulties Bihari patients have in terms of improving their lives and development in their encounters with the healthcare system and as their lives get increasingly 'pharmaceuticalized'. One reason for these difficulties would be the absence of medicines on the shelves of public structures, most notably for chronic diseases. Public facilities do not give regular treatment to chronically ill patients, as this diabetic patient explained to us. He would get only a few days of the treatment he has to take every day: 'They gave me medicines for 3-4 days at the government hospital and said that medicines are not available and I should buy from outside in the market.' ${ }^{27}$ This results in therapeutic trajectories oscillating between public and private sectors, looking for health resources that cannot always be found. Above all, these circulations make access to medicines and prices of medicines contingent, dependent upon the private prescriber. Like this patient explained, there is a strong connection between private providers: 'If I change the doctor, the medicines also change. If I see a doctor and he prescribes me medicines, I will get those medicines only in shops near his clinic. If I see another doctor, the medicines prescribed by him will again be found in 
shops next to his clinic. I cannot find those medicines here. ${ }^{28}$ This can also lead to overprescription, which patients are aware of, as shown in the interviews, without being able to refuse. In turn, out of pocket expenditures are so high that sickness is trapping patients in debt and poverty, like this young man who fell sick at the age of 18, could not work anymore and depended on his brother's earnings to get treated: 'I used to work and earn too. I do not have an estimate of how much I spent but all the family savings were spent there. My brother kept earning and that income also went in the treatment. There was a stage when all money was over and so I stopped treatment.' ${ }^{29}$ In rural areas, $77 \%$ of expenditure on medicines are out of pocket, meaning paid by households (Ministry of Health and Family Welfare, 2005: 186). This situation leads to considerable financial distress for patients in rural Bihar: 'People sell their land, sell the food grains for treatment in the private sector.' ${ }^{30}$ As a result, pharmaceutical lives in Bihar are made of distrust and debt. The major reason for this, as argued in this article, is the government of healthcare through access to medicines in markets which are mostly designed to shift pharmaceutical products. This appears as a paradoxical price to pay for patients living in the 'pharmacy of the Third World'.

\section{Funding}

This research received no specific grant from any funding agency in the public, commercial, or not-for-profit sectors.

\section{Notes}

1. http://pib.nic.in/newsite/PrintRelease.aspx?relid=118620 (last accessed 11 April 2018).

2. Only one pharmaceutical representative was met during the study, his interview was not included in this analysis given the lack of points of comparison.

3. BIMARU is an acronym formed from the first letters of the names of Bihar, Madhya Pradesh, Rajasthan and Uttar Pradesh. It was coined by the demographer Ashish Bose in the mid1980s. BIMARU has a resemblance to the Hindi word 'Bimar', which means sick. This was used to refer to the poor socioeconomic conditions within those states. Since then, several studies have been conducted by economists and demographers, showing that the acronym is still relevant on most social indicators (see among them Sharma, 2015). However, since 2001, the Indian government has opted for a different epithet for these states, the 'Empowered Action Group' (also including today Odisha, Chhattisgarh, Jharkhand and Uttarakhand).

4. Sources: Census of India 2011; Annual Health Survey 2012-2013; WHO, Global Health 2013 Statistics; World Bank, 2014 statistics; SRS (Sample Registration Survey) 2010-2012.

5. See WHO (2016).

6. Interview with the manager of a public health facility at the block level, 12/16, No. 55.

7. Interview with the manager of a public health facility at the block level, 12/16, No. 55.

8. Interview with the manager of a public health facility at the block level, 12/16, No. 55.

9. Interview with a drug inspector at district level, 12/16, No. 111.

10. Interview with a PHC pharmacist, 12/16, No. 52.

11. Interview with ANM at PHC level, 12/16, No. 5.

12. Interview with ANM at PHC level, 12/16, No. 9.

13. Interview with ANM at PHC level, 12/16, No. 54.

14. Interview with ANM at PHC level, 12/16, No. 75.

15. Interview with a rural medical practitioner, $12 / 16$, No. 16. 
16. Interview with a drug inspector, 12/16, No. 111 .

17. Interview with a rural medical practitioner, $12 / 16$, No. 40.

18. Interview with a medical officer in charge of a PHC, 12/16, No. 11.

19. Interview with a patient, $12 / 16$, No. 88 .

20. Interview with a rural medical practitioner, 12/16, No. 14.

21. Interview with a drug inspector at district level, 12/16, No. 111.

22. Interview with a rural medical practitioner, 12/16, No. 91 .

23. Interview with a drug inspector at district level, 12/16, No. 111.

24. Interview with a drug inspector at district level, 12/16, No. 111.

25. Diclovin is an authorized combination of diclofenac and paracetamol produced by Wings Pharmaceuticals based in Delhi. We could not find out if the interviewee was talking about a fake medicine or if he was mixing it up with another medicine. Interview with a drug retailer, 12/16, No. 14.

26. Interview with a patient, 12/16, No. 95 .

27. Interview with a patient, 12/16, No. 67.

28. Interview with a patient, 12/16, No. 93.

29. Interview with a patient, $12 / 16$, No. 88 .

30. Interview with a patient, $12 / 16$, No. 89 .

\section{References}

Banerjee A, Deaton A and Duflo E (2004) Wealth, health, and health services in rural Rajasthan. Papers and Proceedings of the One Hundred Sixteenth Annual Meeting of the American Economic Association San Diego, CA, January 3-5, 2004 (May). The American Economic Review 94(2): 326-330.

Baxerres C (2011) Pourquoi un marché informel du médicament dans les pays francophones d'Afrique? Politique Africaine 123: 117-136.

Biehl J (2007) Pharmaceuticalization: AIDS treatment and global health politics. Anthropological Quarterly 80(4): 1083-1126.

Breman J (1976) A dualistic labour system? A critique of the informal sector concept. Economic and Political Weekly 11(49): 1905-1908.

Breman J (2014) At Work in the Informal Economy of India. New Delhi: Oxford University Press.

Bromley R and Gerry C (eds) (1979) Casual Work and Poverty in Third World Cities. New York: John Wiley.

Callon M and Latour B (eds) (1990) La Science telle qu'elle se fait. Anthologie de la sociologie des sciences de langue anglaise. Paris: La Découverte.

Central Statistics Office (2012) Summary of estimates of GDP. Available at:http://mospi.nic.in/data

Das J (2016) India's informal doctors are assets, not crooks. SciDevNet, 20 April

Das J, Chowdhury A, Hussam R and Banerjee AV (2016) The impact of training informal health care providers in India: A randomized controlled trial. Science 354(6308). DOI: 10.1126/ science.aaf 7384

Das S and Barnwal P (2018) The need to train uncertified rural practitioners in India. Journal of International Medical Research 46(1): 522-525.

Das V (2015) Affliction: Health, Disease, Poverty. New York: Fordham University Press.

Desclaux A and Egrot M (eds) (2015) Anthropologie du médicament au Sud. La Pharmaceuticalisation à ses marges. Paris: L'Harmattan.

Drèze J and Sen A (2002) India: Development and Participation. Oxford: Oxford University Press.

Drèze J and Sen A (2013) An Uncertain Glory: India and its Contradictions. Princeton, NJ:

Princeton University Press. 
Ecks S (2010) Near-liberalism: Global corporate citizenship and pharmaceutical marketing in India. In: Ong A and Chen N (eds) Asian Biotech. Ethics and Communities of Fate. Durham, NC: Duke University Press, pp. 144-162.

Ecks S and Harper I (2013) Public private mixes: The market for anti-tuberculosis drugs in India. In: Biehl J and Petryna A (eds) When People Come First: Critical Studies in Global Health. Princeton, NJ: Princeton University Press, pp. 252-275.

Foucault M (2004) Sécurité, territoire, population. Paris: Gallimard/Seuil.

Gautam CS and Saha L (2008) Fixed dose drug combinations (FDCs): Rational or irrational: a view point. British Journal of Clinical Pharmacology 65(5): 795-796.

Gautham M, Shyamprasad KM, Singh R et al. (2014) Informal rural healthcare providers in North and South India. Health Policy Plan 29(Suppl. 1): i20-i29.

George A and Iyer A (2013) Unfree markets: Socially embedded informal health providers in northern Karnataka, India. Social Science and Medicine 93: 297-304.

Hodges S and Rao M (eds) (2016) Public Health and Private Wealth: Stem Cells, Surrogates, and Other Strategic Bodies. New Delhi: Oxford University Press.

India National Family Health Survey (2005-2006) NFHS_3. Available at: http://rchiips.org/ NFHS/nfhs 3. shtml

India National Family Health Survey (2015-2016) NFHS-4. Available at:http://rchiips.org/NFHS/ factsheet_NFHS-4.shtml

Jeffery P and Jeffery R (2008) 'Money itself discriminates': Obstetric emergencies in the time of liberalisation. Contributions to Indian Sociology 42(1): 59-91.

Jeffery P and Jeffery R (2010) Only when the boat has started sinking: A maternal death in rural north India. Social Science and Medicine 71(10): 1711-1718.

Jeffery P, Jeffery R and Lyon A (1984) Only cord-cutters? Midwifery and childbirth in rural north India. Social Action 34(3): 229-250.

Jeffery P, Jeffery R and Lyon A (1987) Contaminating states: Midwifery, childbearing and the state in rural North India. In: Afshar H (ed.) Women, State and Ideology: Studies from Africa and Asia. Albany: SUNY Press, pp. 152-169.

Joseph RK (2016) Pharmaceutical Industry and Public Policy in Post-Reform India. Abingdon: Routledge.

Kadam AB, Maigetter K, Jeffery R et al. (2016) Correcting India's chronic shortage of drug inspectors to ensure the production and distribution of safe, high-quality medicines. International Journal of Health Policy and Management 5(9): 535-542.

Kamat VR and Nichter M (1998) Pharmacies, self-medication and pharmaceutical marketing in Bombay, India. Social Science and Medicine 47(6): 779-794.

McGettigan P, Roderick P, Mahajan R et al. (2015) Use of fixed dose combination (FDC) drugs in India: Central regulatory approval and sales of FDCs containing non-steroidal anti-inflammatory drugs (NSAIDs), Metformin, or psychotropic drugs. PLoS Med 12(5): e1001826.

May C, Roth K and Panda P (2014) Non-degree allopathic practitioners as first contact points for acute illness episodes: Insights from a qualitative study in rural northern India. BMC Health Services Research 14: Art. 182.

Ministry of Health and Family Welfare (2005) Financing and delivery of health care services in India. NCMH Background Papers.

Peterson K (2014) Speculative Markets: Drug Circuits and Derivative Life in Nigeria. Durham, NC and London: Duke University Press.

Pinto S (2004) Development without institutions: Ersatz medicine and the politics of everyday life in rural north India. Cultural Anthropology 19(3): 337-364.

Pinto S (2008) Where There is No Midwife: Birth and Loss in Rural India (Fertility, Reproduction, and Sexuality, Vol. 10). New York: Berghahn Books. 
Quet M, Pordié L, Bochaton A et al. (2018) Regulation multiple: Pharmaceutical trajectories and modes of control in the ASEAN. Science, Technology and Society. Epub ahead of print 27 April 2018. DOI: 10.1177/0971721818762935

Rao KD, Sundararaman T, Bhatnagar A et al. (2013) Which doctor for primary health care? Quality of care and non-physician clinicians in India. Social Science and Medicine 84: 30-34.

Rao M, Rao KD, Shiva Kumar AK et al. (2011) Human resources for health in India. The Lancet 377: 587-598.

Rao MG and Choudhury M (2012) Health care financing reforms in India. Working Paper No. 2012-100, March,National Institute of Public Finance and Policy, New Delhi.

Roitman J (2005) Fiscal Disobedience: An Anthropology of Economic Regulation in Central Africa. Princeton, NJ: Princeton University Press.

Saldaña J (2009) The Coding Manual for Qualitative Researchers. Los Angeles: Sage.

Sassen S (1994) The informal economy: Between new developments and old regulations. The Yale Law Journal 103(8): 2289-2304.

Sharma V (2015) Are BIMARU states still bimaru? Economic and Political Weekly 50(18).

Sunder Rajan K (2017) Pharmocracy: Value, Politics, and Knowledge in Global Biomedicine. Durham, NC: Duke University Press.

Thakur D (2016) The real story behind drug approvals. The Hindu Business Line, 19 April. Available at: www.thehindubusinessline.com/opinion/the-real-story-behind-drug-approvals/ article8495087.ece

WHO (2016) The health workforce in India. Human Resources for Health Observer Series No. 16 , June.

\section{Author biographies}

Marine AI Dahdah is a sociologist and a postdoctoral fellow at IFRIS-Cermes3 (Paris) and a CSHDelhi research associate. She holds a PhD in Sociology from Paris Descartes University. She has been working on the use of mobile phones and digital tools to improve health in Asia and Africa.

Aalok Kumar is an independent researcher, in past years he worked for the World Bank in Bihar to support their health interventions with women self-help groups. His areas of research include digitalization of health and community health. He was trained in public health management from IIHMR, New Delhi

Mathieu Quet is a research fellow at CEPED (UPD-IRD). He is currently a hosted researcher at Jawaharlal Nehru University, New Delhi. His research analyses pharmaceutical flows and regulatory politics between India and Kenya. He is author of Impostures pharmaceutiques. Médicaments illicites et luttes pour l'accès à la santé (Paris: La Découverte, 2018)

\section{Résumé}

À partir de recherches menées dans le Bihar (Inde), nous soutenons dans cet article que dans le nord de l'Inde l'accès aux médicaments par des voies informelles constitue un élément essentiel dans l'administration des soins médicaux. Dans le Bihar, les prestataires informels, tels que les médecins de village et les vendeurs de médicaments non agréés, jouent un rôle fondamental dans l'accès aux médicaments, notamment dans le contexte du démantèlement des services publics d'approvisionnement. En exploitant les résultats de travaux récents sur la socio-anthropologie des produits pharmaceutiques, cet article signale l'importance de prendre en considération l'économie politique des médicaments en Inde pour mieux appréhender les problèmes locaux d'accès. Sur la base d'entretiens avec des professionnels de la santé et des patients, nous dressons d'abord un état des lieux des soins de santé publics et des services publics d'approvisionnement 
dans le Bihar; puis nous décrivons le rôle des fournisseurs informels de médicaments; enfin, nous montrons comment les patients surmontent le fait de vivre dans un « monde pharmaceutique » où avoir accès aux soins revient à avoir accès aux médicaments.

\section{Mots-clés}

Accès aux médicaments, Bihar, Inde, marchés informels, services publics d'approvisionnement, sociologie de la santé

\section{Resumen}

A partir de los resultados de una investigación en Bihar, India, este artículo argumenta que el acceso informal a los medicamentos en el norte de la India es un elemento central en la gestión de la asistencia sanitaria. Los proveedores informales, como los médicos rurales sin licencia y los vendedores de medicamentos, desempeñan un papel importante en el acceso a los medicamentos en Bihar, especialmente en el contexto del desmantelamiento de los servicios de provisión pública. A partir de trabajos recientes en socio-antropología sobre los productos farmacéuticos, este artículo demuestra la importancia de tener en cuenta la economía política de los medicamentos en la India, a fin de comprender los problemas locales de acceso de manera más completa. A partir de entrevistas con profesionales de la salud y pacientes, el artículo describe primero la situación de la salud pública y de la provisión pública en Bihar. Luego describe el rol de los proveedores informales de medicamentos. Y, por último, demuestra cómo los pacientes lidian con el hecho de vivir en un 'mundo farmacológico' en el que el acceso a la salud es equivalente al acceso a los medicamentos.

\section{Palabras clave}

Acceso a medicamentos, Bihar, India, mercados informales, provisión pública, sociología de la salud 